\section{Impact of Price and Service Quality on Brand Loyalty in Telecommunication Industry: The Mediating Effect of Customer Satisfaction}

\author{
Myra Waqar ${ }^{1}$, Aima Khan ${ }^{2}$
}

The Journal of Educational Paradigms 2020, Vol. 02(01) 103-111

(c) Authors

ISSN (Print): 2709-202X

ISSN (Online): 2709-2038

DOI: $10.47609 / 0201052020$

\begin{abstract}
The main reason for conducting this research is to study that how brand loyalty has been affected by price and service quality in telecommunication industries operating in Pakistan. This study addresses the main issue that whether the price and service quality has improved or reduced the significance of brand loyalty. The main reason for conducting this research is to investigate the casual-effect relationship between brand loyalty and the effect of price; similarly, brand loyalty and the effect of service quality and mediating effect of consumer satisfaction with the moderator as level of trust. This research has two independent variables, one moderating and one mediating variable which influence one dependent variable. Independent variables are price and service quality, moderating variable as level of trust and mediating variable as consumer satisfaction, whereas, brand loyalty as a dependent variable keeping all other factors constant. The method used for this research is quantitative; whereas questionnaire is used as an instrument for data collection. Moreover, this research has been chosen three university as population and the students of BS and MS (Business Administration) as the sample for this study. As telecommunication industry is rising lavishly in Pakistan and there is a lot of competition going on between the various networks operating in Pakistan. The findings of this research has helped the industry as well as customers; for industry, this study has helped them to generate such policies which would be best for their customers by getting some insight about the factors affecting the loyalty of the customers to their telecommunication company. Similarly, the customers would get to know which service provider is the best for them.
\end{abstract}

Keywords: Brand loyalty, Service Quality, Price, Trust, Customer Satisfaction, Telecommunication Industry.

Use of mobile phones are very common nowadays. Every person is indulged in telecommunication industry. Brand loyalty has been vital part of marketing from the very beginning. Service and quality provided by any subsidiary make the costumer attract or lose interest in their business. It make things easier for a consumer to buy products without giving it a thought and it is of great value now a days, consumers who have a keen affection for a brand spare not as much of time while making any decision for that service or product. (Co-branding and Branding Loyalty, 2007 a ) [Narrative Hook] Every consumer has its own set of taste, so the companies should produce things which is at least liked by their target customers. Price is a major issue because of inflation going on. Service is also another variable which makes a costumer satisfied even if the prices are high and keeping trust of a customer is quite difficult nowadays. There are five variables in this research.

- Price

- Service Quality

- Brand loyalty

- Customer Satisfaction

- Level of trust

Moreover, service and price have excessive influence on brand loyalty which helps in creating trust and to satisfy the customer. In telecommunication industry the competition is very tough, because every company is struggling hard to keep itself in the race. It is tough in a sense, as customers are experiencing things and then making decisions instead of listening to it. Customers are very aware of brand loyalty and they know what is best for them. So the telecommunication industry should work hard. The topic is neutral because it is not telling the exact findings of this research unless or until the reader reads it. The impact can be positive or negative which is totally dependent on the customer.

\section{Research Problem}

Telecommunication industry has taken a lot of steps in the revolutionary world. It has created a great competition with number of increasing customers every day. Moreover, in this decade customers have the edge and technology to switch to any other network without changing their number. This is the main reason telecommunication industry is facing a lot of trouble and tension. This switching of network with similar digits is known as Mobile Network Portability (MNP) (Bojei, 2013) people talk through mobile phones. So basically, it is the core part of this revolutionary world. (Bojei, 2013) Moreover, the main issue going on for the industry is, customers are free to change their networks even with a slight negligence. The main challenge for the business is to keep them brand loyal by creating the best price packages and good service quality. Brand loyalty nowadays is very difficult because consumers can easily move to other brands when they feel a slight change in price or quality in their attitudes.

Consumers do not think of the brand, they basically think of their benefits. If one brand is providing a better quality with minimal price the customer will for sure switch to that network and the best thing is it not even required to change their number. Price and quality are two factors which inter-relate each other. If price goes up but the quality gets down, the brand will lose their customers. Similarly, if the price goes down and the quality remains the same,

${ }^{1}$ UCP Business School, Faculty of Management Studies, UCP, Pakistan. 
customer will be happy with that brand. The main problem which companies should ponder about, is that they must make a strategy which will keep their customers, because switching to other networks these days is very easy. This is basically a social issue which is very common these days. The wave of this change can also be seen all over the country. This technology has changed the lives of customers and their retailers. Companies should focus on this issue because it is making the customers less loyal towards a brand. Because it is not only losing their customers but also losing their shares, as the customers are their revenue generators-if they lose them, they will lose their shares too. This is the financial implication which is being faced by the retailers and companies. Furthermore, this is main reason telecommunication industry must do something to make their customers brand-loyal because they have easy way to get rid of that network if they face any issue.

\section{Background}

At the very beginning of telecom industry, it started with PTA in 1994. The first service provider company was insta-phones which further merged with Jazz in late 90s. (google scholar, n.d.) Adding on to it, there were five major providers which were,

- Mobilink with a share of 59 million subscribers

- Warid (merged with jazz now)

- Telenor with a share of 29.3 million

- Zong with a share of 15.6 million

- Ufone with a share of 23.6 million (google scholar, n.d.)

After 2015, Mobilink was merged with warid and now they are at the top of market share in the industry. According to population of Pakistan, every customer has its own set of demands and decisions. Around $90 \%$ of Pakistanis are using this technology. Depending upon their needs, they select their network. The selection of their network totally depends upon their own choice and experience. At first there was no choice of switching to other networks without changing their number. But now customers have the edge that they can shift to any other network if they feel any difference in price and service quality in their network. Brand loyalty is what when customer has a specific kind of trust on his or her selected brand. The reason for being brand loyal totally depends upon customer's thoughts and needs. It can be any variable, price, quality, satisfaction or others. But in this research two variables are chosen, i.e. Price and Service Quality- because these two variables have more impact on brand loyalty. Retaining customer is a very challenging task for any brand.

\section{Research Gap}

Pakistan has grown a lot in the business of telecommunication industry. PTA has shown the stats that around $150 \%$ consumers have increased in mobile sector up till now. (2003-2006) (pta.gov.pk, n.d.) Furthermore, these days the biggest challenge for any brand is how to satisfy their customer, maintain their trust and keep them brand-loyal, which is a very challenging task. Because every customer has its own set of needs and desires. The brand should understand the mind of costumers to be successful in their business. They should see what a customer wants. Three important variables price, service quality and consumer satisfaction show the independent and meditating effect on brand loyalty. These customers give companies profit and benefits which makes a customer big asset for them. (Bojei, 2013) A vast amount of literature on brand-loyalty is already available with price and service quality but a very less amount of literature is available in the context of telecommunication industry. This is main reason for conducting this research in telecommunication industry. It will enhance the literature, because nowadays these companies are very important for communication purposes. Everyone is using telecom services for communication purposes. Furthermore, brand loyalty in telecommunication industry is indulging topic these days and a lot people want to know about it. This will not only increase the literature but also increase the knowledge.

\section{Significance}

Customer satisfaction, customer shares, earning profits through customers are the main things for the industry which are at the top of priority list, which they are working for. Customer satisfaction totally depends according to the need of costumers. To satisfy customers is a difficult task because they can easily change their network without any issue. So, the companies should use such tactics and strategies where they can satisfy their customers, generate their trust and make them happy and satisfied. (Oliver R. , 1999) A very low literature in available in the context of telecom sector. Adding on to it switching to other networks easily are making things worse for the companies. So this research, would be important for the industry because they would get to know what is happening in the market and in the mind of customers. Plus, this would help the industry to change their tactics and strategies according to the need of customers. This would also help the companies to reform their policies of price and services according to the consumers.

\section{Research Objectives}

The objectives which we have tried to achieve in our research project is as under:

- To identify the effect of price and service quality on brand loyalty in telecommunication industry.

- To identify the mediating impact on customer satisfaction with price and service quality on brand loyalty in telecommunication industry.

- To identify the moderating impact of level of trust on brand loyalty in telecommunication industry.

\section{Research Questions}

Three research questions are identified. Which are as follow:

RQ1: What is the effect of Price and Service Quality on brand loyalty in telecom industry?

RQ2: What is the mediating impact of customer satisfaction on Price and Service Quality on brand loyalty in telecom industry?

RQ3: What level of trust is affecting the customer satisfaction and brand loyalty in telecom industry?

\section{Literature review}

Telecommunication industry has taken a lot of steps in the revolutionary world for example, in 2013, (Bojei, 2013)argued that changing networks is getting very easy these days. This is the main reason telecommunication industry is facing a lot of trouble and tension. This switching of network with similar digits is known as Mobile Network Portability (MNP) (Bojei, 2013) people talk through mobile phones. So basically, it is the core part of this revolutionary world. Furthermore, it is stated by (Oliver R. , 1999) retainig customers is very tough these days. It is somewhat easy 
for the customers to change according to their need but difficult for the service company to keep their bussiness going.

There can be two kind of consumers a service provider could have, prior are the active customers whereas latter are the passive customers. In the case of active customers the switching to other networks is quiet high, (Loyalty.., 2007(a)) Latter customers are not aware of their packages and they get know about them through their massive advertising. (Loyalty., 2007b)before the technology named as, MNP people were restriced to their old network even if they wanted to shift to other network, because of the number they are using. But now as you can clearly see that there is this new expertise of shifting to other networks without changing your network; so, elements like,

1. Price or

2. Service Quality

3. Level of trust

4. Customer satisfaction

Have a great impact on costumers regarding the dependent variable which is brand loyalty. (Loyalty., 2007b)

\section{Explanation and Magnitudes of Variables}

\section{Brand Loyalty}

Describing the term, it occurs when a costumer or a consumer buy products from the same brand repeatedly instead of buying substitute products from their competitors. Brand loyalty is, however, often produced on perception. By perception we mean, to own your thoughts and to develop your own reality. A costumer will repeatedly buy the product because he/she likes the product of that brand. For example, some consumers will always purchase Pepsi at a departmental store, whereas other consumers will purchase Coke. Brand loyalty is a term which was known in 1920. The focus of the companies for their continuous growth and support of customer loyalty towards a brand or a product totally depends upon the strategies they use to retain customers. The idea is grasped in the marketplaces as the alternative's products are competing in markets with low level of differentiation. The word of mouth good or bad depends upon the perception of a brand in the mind of customer which make them loyal or disloyal.

In this research, brand loyalty would be taken as a challenge to satisfy the customers.

\section{Significance}

Brand loyalty give a great impact to the market researchers who are providing the services and consumer researchers to whom the services are being provided. In terms of services, loyalty is basically the love of a customer towards a brand. Those firms incline to have more revenues and investments who have higher level of loyal customers. Such outcomes inspire and motivate marketers to keep those loyalists, because they generate a huge revenue for a firm. To achieve such targets, marketers need to ponder about their interests. (Chao-Chin, 2017) (Oliver R. , 1999) Stated that, consumer faithfulness is guaranteed with encouraging word of mouth. More the word of mouth more the attraction of consumers near a brand.

Word of mouth can be from your peers, your family, your friends or even your company groups. Customers are attracted towards a brand because of some reasons; services provided by the brands, pricing policies by the brands and the quality of their products.
Loyal customers are active users of a brand who generate a huge revenue for the firm. Firms can easily retain them by their services and prices keep going.

A faithful and pleased consumer can be helpful to increase the comparative negotiating influence of administrations concerning dealers, associates and stations. For example, if the loyal customers are only buying from a brand then the revenue of that brand continuously being produced. (Diallo, 2015) Competitive tactics and positive word of mouth can be battled by customer's brand loyalty. Based on 20-80 rule, $20 \%$ of a brand's faithful consumers can make $80 \%$ revenue for the organization (Diallo, 2015) more the loyal costomers, more revenue of that brand.

\section{Price Strategy}

Price can be defined as a term, by which amount you are buying a product and how much they are demanding for that product or service. The factors which effect Price include; different correspondences with dissimilar set of prices for every customer. Nowadays, because of high level of competitors, the telecommunication service providers use different price and services tactics to retain their customers.

However, it has argued that marketers used two kind of pricing strategies either the time of penetration in the market or to counter the competition. Accordingly, Koller suggested that marketers use penetration strategy when they want to enter in perfect competitive market environment in order to counter the competition as well as to erode the competitive advantage of other market players. Similarly, when organizations have a unique or innovative product/service in their hand, then they choose skimming pricing at the time of penetration in the market. Although, skimming pricing strategy is favorable in monopoly most of the time while it could also generate the profits in competition if the brand has strong image and robust customer based brand equity (see) (Koller, 2015)

In addition to the above, numerous researchers highlight the importance of pricing and pricing strategies. For example, (Koller, 2015) argue that when company adopt selling concept for their products and service, then pricing strategies play a fundamental role in the success of that product and services. (Jamshidi, 2018)) suggested that, pricing could be the most important touch point for the customer particularly when companies are dealing with mass markets. This is because, by using the effective pricing strategies (perfect match with the offerings and buying power of the target audience) an organization may erode the competition while build a long-lasting competitive advantage. Despite the importance of pricing, pricing strategies play central role in making the consumers' perception about that product/service. For instance, if a company use penetration pricing strategy while targeting a niche market whose buying power is very high, then it may create the negative perception about product quality or people may conceive that brand as a cheaper brand. In contrast, if an organization use skimming pricing while targeting mass market in the state of perfect competition, then customer may perceive the product/service negatively (this product is far much costly while having the same features and quality as others).

Accordingly, Price plays a huge part in telecommunication sector. Pakistan is a developing country where most of the consumers are 
middle class. (Moreira, 2017)In addition, Moreira and his colleagues (2017) argue that Price is one of those structures that can appeal or keep consumers. Perceived price is a qualitative approximation by the consumer about the competitive price for same invention or service of a brand. Hence, price is the fundamental touch point for the customer meanwhile pricing strategies play important role in shaping the consumer perception.

\section{Association between Price and brand loyalty}

Pakistan has customers who are inclined towards low charges with high level of service quality whether it is a product or service. A country which we are living in, is mostly based on middle class mostly based on middle class, because of this factor every marketer is reducing his prices to retain customers. (Mustafa, 2019). Customers mostly get involved to those sim carriers who have low prices. (Malik, 2012) Sim carriers, in order to make consumers happy, firms should lower their prices to retain their satisfied customers. Customers are a great benefit for firm these days, because of this; firms are going towards customization which is attentive of a great contract on customer relationship Management (CRM) (Natalia, 2015). In addition, if a company introduces a unique and innovative product/service then it may set skimming pricing. Because, (Koller, 2015) argue that skimming price is best strategy for innovative and novel products and services while penetration pricing is favorable, when organization's objective is to erode the competitive advantage of their competition and to establish new competitive advantage. Less the prices than the competitor more the customers stay loyal.

H1a: Price has a positive and significant effect on brand loyalty

H1b: Price has a negative effect on brand loyalty

\section{Service Quality}

Service quality can be defined as the complete valuation of the brand, of what a costumer perceives about that brand before using it and after experiencing its services. However, (Koller, 2015) argue that there are always some utilitarian and hedonic features attached with a particular product or service and the quality of a product/service is comprised by this mixture of utilitarian and hedonic features. However, (Jamshidi, 2018) argue that utilitarian feature of a product/service could be described as those features for whom a customer pay directly and also experience directly. For example, if a customer is using a WIFI of PTCL, he must pay for the Mb's that he/she is consuming. On the other hand, hedonic features of a product/service could be defined as those, for which customer do not pay directly and experience these features indirectly (Koller, 2015) ( a person is not paying for the after sales services to PTCL-BB that they are providing along with WIFI connection). In our research, service quality is stately one of the main factors of satisfying the customers. Moreover, it also includes the signal quality of a service provider despite of the fat that what weather conditions they are or in which you are.

Different set of packages being provided by network carriers for customers of different classes

These few factors have a great impact on service quality, and this is how a customer becomes brand loyal towards a brand. Service Quality can also be distinct as what a customer perceived and what they received from the service provider. In addition to it, (Mustafa, 2019)argue that service quality is a phenomena of consumer perception. (Jamshidi, 2018) Critically mentioned that service quality plays a central role in encouraging or discouraging the consumers toward shopping. We suggested that, a perfect combination of utilitarian and hedonic features could robust the quality of a service which could create the positive perception among consumers regarding brand and vice versa.

\section{Relationship between Service Quality and brand loyalty}

Service business has countless number of competitors because of the sim carriers having a slight difference in their packages and services. Main reason of using Sims is to communicate through them without any issue and if the quality of their chosen carrier is low then customers would question their loyalty once. Thus, Moreira and his colleague argue that are distant to differentiate due to their four features of inseparability, intangibility, perishability and variability. (Moreira, 2017) Furthermore, (Mustafa, 2019) argue that customer purchase and repurchase of a particular product/service or brand could be effected by its service quality. Thus, there can be numerous ways through which marketers can keep their customers satisfied and happy.

H2a: Service quality has a positive and significant effect on brand loyalty

$\boldsymbol{H} 2 \boldsymbol{b}$ : Service quality has a negative effect on brand loyalty

\section{Customer Satisfaction}

Customer satisfaction can be defined as, to please and satisfy the consumer for the service or product a brand is providing. Every customer has a different mind-set which makes it quite difficult for a service provider to make them satisfied and loyal towards them. Nowadays, price and quality are an important aspect which can easily change the perception of a customer. By charging fair prices for better quality, a provider can satisfy their customers. A hypercompetition has been created which is affecting the shares of providers. Every costumer desires his safety and want himself to be pleased and satisfied. (Anderson, 1993) Has claimed that, every customer desire best service and when the customer come again to re-purchase it increases the value of the product/service. By providing them, best quality and price it will make it easy to satisfy a customer. Because negative impression can reduce the sales but positive impression which can be created by providing them excellent services and generating trust would help them to increase their sales and revenues. (Swartz, (2000)) It is important for a provider to know exactly about the needs of their costumers, it can happen that if a provider is providing excellent services to the costumer but it is not useful for him or he does not need it, this will create dissatisfaction in the mind of customers.

It can be said that, satisfaction can be changed at any point because it is all dependent on the costumer. And if the providers take a positive meaning of this, they can try utmost to increase their satisfaction and pleasure. Satisfaction also helps in creating loyalty towards your product. As a marketer, marketing strategies can be changed, managed, maintained at any point or when in need, this will help the provider to increase its sales and to satisfy the costumers. (Baghestani, 2017) Satisfaction is different for different costumers, because of the sources they get information from. For example, word of mouth, inner self, family, friends and colleagues, all can easily affect the satisfaction of a consumer. If a 
provider wants to make him satisfied, he should create policies that is important for the customer.

Relationship between customer satisfaction and brand loyalty Customers who keep on buying the same product or service from the same subsidiary, we can say that these customers are loyal towards that specific brand or product. Many variables can affect loyalty of a customer. If we talk about satisfaction, if a customer is pleased, he can be loyal towards a brand but if he is not than loyalty is doubtful. If a customer is loyal, he sees a deadly combination between price and quality for that product which obviously includes satisfaction of that customer. (Gustafsson, 2004).

H3: Consumer satisfaction has a positive and significant effect on brand loyalty

Relationship between the mediating effect of customer satisfaction between price and brand loyalty

In order to create loyalty and satisfaction customers should be given such products which are important to them, because if a product is expensive but has no value for the customer, it is of no use. (Diallo, 2015) Every customer has a different sort of choices which can be changed according to their taste, their sources through which they are connected. Without the level of satisfaction, we cannot generate loyalty for a brand. And loyalty comes with better pricing. For some customers, price is an important factor. As a country like Pakistan, where inflation rate is high, unemployment rate is high and GDP rate is low, customers' top priority is the price. (Natalia, 2015) So, if the prices are low and according to the need of consumers, they will be satisfied which simply make them loyal towards that brand.

H4: Customer satisfaction mediates the relationship between pricing strategy and brand loyalty

Relationship between the mediating effect of customer satisfaction between service quality and brand loyalty

Service quality is said to be the perception in the mind of customers before using a product and experience after using it. As described earlier about the price, similar is the case with quality. Quality is also an important variable in the mind of a buyer. It can easily make someone loyal and satisfied towards them. Service quality explains us the reliability, assurance and the responsiveness of a brand. Customer satisfaction plays a mediating effect because it legibly explains the relation. (Pitt)

H5: Customer satisfaction mediates the relationship between service quality and brand-loyalty

\section{Level of trust}

Trust can be stated as, "any level through which you maintain the desired relationship". Trust is the continuous interest in something and to keep it going. Trust and commitment should be associated together because they both are on the same pace. A customer develops trust based on experience with the desired brand. Trust can be created by any contact. It can be direct or indirect. (wordof-mouth, advertisement, reputation of the brand, perception about the brand) etc. Satisfaction is an important concept which generates level of trust. Trust can be high or low depending upon the experience of a consumer. (Schlesinger, 2017)

Relationship between the moderating effect of level of trust between customer satisfaction and brand loyalty
Every study has showed that trust brands are more in demand and it helps in increasing the revenue and sales of the retailer. Price and service quality can easily generate trust, because it a provider is promising to give them less prices with better services this will produce trust in the mind of costumers towards that brand. To generate a long-term relationship every provider should create trust in their costumers. Level of trust is high and low depending upon the fulfilment of the provider. Therefore, trust is an important variable which mediates the association between customer satisfaction and brand loyalty. (Schlesinger, 2017)

H6: Customer level of trust moderates the relationship between customer satisfaction and brand loyal

Conceptual Framework

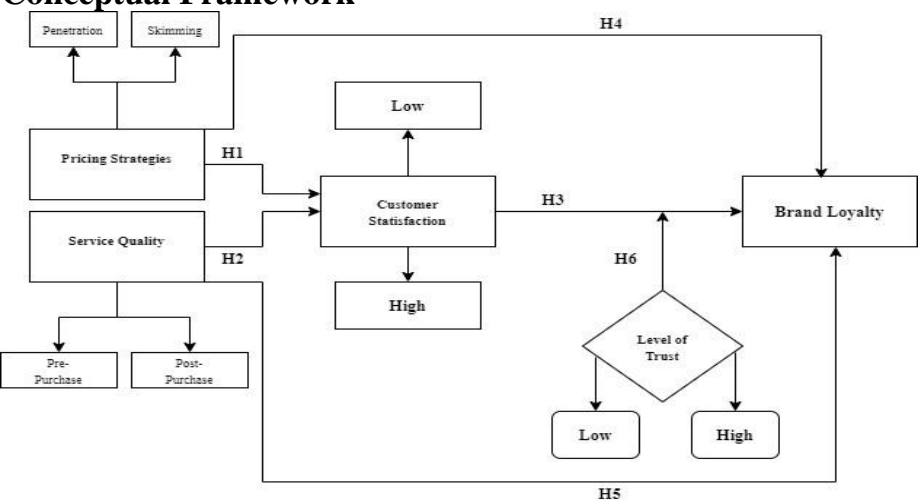

Figure 1: Conceptual Framework

This shows that how price and service is affecting brand loyalty of a customer being a dependent variable with customer satisfaction as a mediator and checking the relationship with level of trust as a moderator.

\section{Research Methodology}

The methodology followed by the researcher is Quantitative method. Because a lot of research has been done on brand loyalty but a very less literature is available in Telecommunication context. Questionnaires were used to collect the data.

\section{Research Design}

The research design would define the effect of independent variables on the dependent variable which is price and service quality as independent whereas Brand loyalty as dependent variable, with the mediating effect of customer satisfaction and level of trust as a moderator, keeping all other factors constant.

Instrument Development:

\section{Adaption/Adoption of the Questionnaire}

The primary data had been collected through online supervision of questionnaire. Instrument is adopted/adapted through different articles of brand loyalty which is mentioned below and in the reference list.

\section{Measurement of the Questionnaire}

Measurement of the questionnaire has been done through five likert scale which are as under;

- Strongly Disagree

- Disagree

- Neutral

- Strongly Agree

- Agree 


\section{Which question is measuring which variable?}

This research has five main variables respectively. Price and service quality are operational as Independent variable whereas Brand loyalty is dependent upon these two variables having a causal-effect relationship and customer satisfaction acting as a mediator whereas level of trust(moderator) is explaining the relationship between price and service quality keeping all other variables constant.

In the questionnaire, which is attached in the appendix has following questions measuring these three main variables:

- From Question 1 to Question 8, we can say that these question items are measuring Brand Loyalty with the mediating effect of customer satisfaction and level of trust as a moderator.

- From Question 9 to Question 17, we can say that they are measuring effect of price on brand loyalty with the mediating effect of customer satisfaction and level of trust as a moderator.

- Moreover, from Question 18 to Question 24, it can be stated as that these questions are measuring the effect of Service Quality on brand loyalty with the mediating effect of customer satisfaction and level of trust as a moderator.

We have developed a questionnaire which has 30 Items. 6 were developed as demographic items by the researcher. 8 items were constructed for the variable 'Brand loyalty' with the mediating effect of customer satisfaction and level of trust as a moderator, i.e. 2 question items were adapted from (Delgado-Ballester \& Yague-Guillen, 2003) other 3 were adapted from study of (Kabadayi, 2012) whereas a scale of 3 items were adopted from the study of (Punniyamoorthy, 2007). After that other two independent variables were also measured by various scale items. For the Independent variable 'Price' 9 items were adopted from 3 scales. 4 items were adopted from the study of (Punniyamoorthy, 2007) whereas 1 item was adopted from the study of (Netemeyer, 2004) moreover, a scale of 4 items was taken from (O'Cass, 2011). Talking about the last independent variable 'Service Quality' a scale of 7 items was adopted from the study of (Gorla, 2010) and moderator level of trust where 4 items are selected from (DelgadoBallester \& Yague-Guillen, 2003) in order to measure the effect of these two independent variables on Brand loyalty (Dependent Variable) with the mediating effect of customer satisfaction and level of trust as a moderator.

\section{Data Access}

Access of data would not be a difficult task for this sample because we have gatekeepers in the universities. The only thing which is required is to set a meeting with Dean of these universities and a permission letter should be signed by the deans of these institutes.

\section{Sampling strategy}

\section{Sampling Unit and Sample size}

The data for this dissertation has been collected from three universities located in Lahore. The name of these institutes are University of Central Punjab, University of the Punjab and University of Lahore. The sample is of students and employees of the universities. The total number of participants are 80 . The reason for choosing 80 participants was because of the time constraints and the pandemic going on in the whole world.

\section{Sampling Method}

Probability Random Sampling has been done and participants have asked to fill in the questionnaire in order to get the desired results of the thesis. In random sampling everyone has the chance of being selected, so does in our research.

\section{Nature of the study}

As we have a certain time-period to complete this research, so we will use cross-sectional study. "Cross-sectional design represents data collection on subsets of a population in a given time-period" (Bryman, 2004)

\section{Reason for selecting Questionnaire}

The reason for selecting questionnaire as instrument is that, as questionnaire has high efficiency and effectiveness as they keep the participants anonymity. Results can be well constructed by finding the reliability and validity of the data. No other strategy had that comprehensive competence. Another reason which made by the researcher to choose questionnaire is that this design is quite flexible than other qualitative designs. Questionnaires can also be filled through online administration. Furthermore, they are also inexpensive. And, in order to sustain assessment on neutral evidence and compare the results properly, researcher chose this instrument.

\section{Participants}

The questionnaire was completed by the students and employees of University of Central Punjab, University of the Punjab and University of Lahore which were selected randomly based on the use of mobile networks.

\section{Results}

Table 1: Reliability Statistics

\begin{tabular}{cc} 
Cronbach's Alpha & N of Items \\
\hline .773 & 5 \\
\hline
\end{tabular}

A reliability analysis has been conducting against each variable. For that purpose, we use the value of Cronbach's alpha to ensure the reliability of the variables.

As above table highlights that the Cronbach's value of all variables, are above than the threshold level of .70. Hence, all instruments that have used in this research to measure respected variables are highly reliable.

Table 2: Descriptive statistics

\begin{tabular}{|c|c|c|c|c|c|c|}
\hline & & $\begin{array}{c}\text { Customer } \\
\text { Satisfaction }\end{array}$ & $\begin{array}{l}\text { Brand } \\
\text { loyalty }\end{array}$ & Price & $\begin{array}{l}\text { Service } \\
\text { Quality }\end{array}$ & Trust \\
\hline \multirow[t]{2}{*}{$\mathrm{N}$} & Valid & 64 & 64 & 64 & 64 & 64 \\
\hline & Missing & 0 & 0 & 0 & 0 & 0 \\
\hline \multicolumn{2}{|c|}{ Mean } & 3.5469 & 3.5026 & 3.3789 & 3.4085 & 3.5391 \\
\hline \multicolumn{2}{|c|}{ Median } & 4.0000 & 3.5000 & 3.5000 & 3.4286 & 3.7500 \\
\hline \multicolumn{2}{|c|}{ Mode } & 4.00 & $3.00^{\mathrm{a}}$ & $3.50^{\mathrm{a}}$ & $3.14^{\mathrm{a}}$ & 4.00 \\
\hline \multicolumn{2}{|c|}{ Std. Deviation } & .75445 & .71300 & .62519 & .54761 & .64275 \\
\hline
\end{tabular}

As above table highlights the descriptive statistics of our variables. In addition, table shows the mode, mean and median of the statistics.

Table 3: Regression

\begin{tabular}{ccccc}
\hline Model & $\mathbf{R}$ & $\begin{array}{c}\mathbf{R} \\
\text { Square }\end{array}$ & $\begin{array}{c}\text { Adjusted R } \\
\text { Square }\end{array}$ & $\begin{array}{c}\text { Std. Error of the } \\
\text { Estimate }\end{array}$ \\
\hline 1 & $.636^{\mathrm{a}}$ & .405 & .385 & .55903 \\
\hline
\end{tabular}

a. Predictors: (Constant), Service Quality, Price

In above table, the value of $\mathrm{R}$ square is .405 . It states that Independent variables (Service Quality and Price) explains $40 \%$ of the Dependent variable (Brand Loyalty). 
Table 4: ANOVA

\begin{tabular}{llccccc}
\hline & Model & $\begin{array}{c}\text { Sum of } \\
\text { Squares }\end{array}$ & df & $\begin{array}{c}\text { Mean } \\
\text { Square }\end{array}$ & F & Sig. \\
\hline 1 & Regression & 12.964 & 2 & 6.482 & 20.741 & $.000^{\mathrm{b}}$ \\
& Residual & 19.063 & 61 & .313 & & \\
& Total & 32.027 & 63 & & & \\
\end{tabular}

a. Dependent Variable: Brand Loyalty

b. Predictors: (Constant), Service Quality, Price

As above table highlights that the overall significance value of all variables, it is less than the threshold value 0.05 . Hence, all instruments that have used in this research to measure respected variables are highly significant.

Table 5: Coefficients

\begin{tabular}{llccccc}
\hline Model & \multicolumn{2}{c}{$\begin{array}{c}\text { Unstandardized } \\
\text { Coefficients }\end{array}$} & $\begin{array}{c}\text { Standardized } \\
\text { Coefficients }\end{array}$ & t & Sig. \\
\cline { 3 - 5 } & B & Std. Error & Beta & & \\
\hline 1 & (Constant) & .249 & .526 & & .473 & .638 \\
& Price & .238 & .116 & .209 & 2.049 & .045 \\
& Service & .719 & .133 & .552 & 5.417 & .000 \\
& Quality & & & & & \\
\hline
\end{tabular}

a. Dependent Variable: Brand Loyalty

In above table, the Beta value of Price is .209 which means relationship exist between Price and Brand Loyalty. Similarly, value of Service Quality is .552 which means a relationship exist between Service Quality and Brand Loyalty.

\section{Mediation effect on consumer satisfaction}

Regression analysis of whole model for this study in relation with mediator is also calculated by using process, by Andrew F. Hayes. According to the results, mediation does not exist because, the value of Boot LLCI (Lower Limit Confident interval) is -.1782 and value of Boot ULCI (Upper Limit Confident Interval) is .2381. This shows that both values are opposite in direction and creates an insignificant effect on each other.

\section{Hypothesis Testing (T-Test)}

Table 1: Price has a significant effect on brand loyalty.

\begin{tabular}{lcccccc}
\hline & $\mathbf{t}$ & df & $\begin{array}{c}\text { Sig } \\
(\mathbf{2 -} \\
\text { tailed })\end{array}$ & $\begin{array}{c}\text { Mean } \\
\text { Difference }\end{array}$ & & \multicolumn{2}{c}{$\begin{array}{c}\text { 95\% Confidence } \\
\text { Interval of the } \\
\text { Difference }\end{array}$} \\
\cline { 5 - 7 } & & & & Lower & Upper \\
\hline Price & 43.237 & 63 & .000 & 3.37891 & 3.2227 & 3.5351 \\
Brand & 39.300 & 63 & .000 & 3.50260 & 3.3245 & 3.6807 \\
\hline
\end{tabular}

According to the above table, price has positive and significant effect on brand loyalty. Because the significant value is less than threshold value $(\mathrm{P}<0.05)$; that shows the significant effect of price on Brand loyalty.

Table 2: Service quality has a significant effect on brand loyalty

\begin{tabular}{lcccccc}
\hline & $\mathbf{t}$ & $\mathbf{d f}$ & $\begin{array}{c}\text { Sig. } \\
\mathbf{( 2 -} \\
\text { tailed) }\end{array}$ & $\begin{array}{c}\text { Mean } \\
\text { Difference }\end{array}$ & \multicolumn{2}{c}{$\begin{array}{c}\text { 95\% Confidence } \\
\text { Interval of the } \\
\text { Difference }\end{array}$} \\
\cline { 3 - 7 } & & & & Lower & Upper \\
\hline Brand & 39.300 & 63 & .000 & 3.50260 & 3.3245 & 3.6807 \\
Service & 49.794 & 63 & .000 & 3.40848 & 3.2717 & 3.5453 \\
\hline
\end{tabular}

This hypothesis is accepted because the significant value is less than threshold value $\mathrm{P}<0.05$; that shows that service quality has significant and positive effect on Brand loyalty.

Table 3: Consumer satisfaction has a positive and significant effect on brand loyalty

\begin{tabular}{cccc} 
t df & $\begin{array}{c}\text { Sig. (2- } \\
\text { tailed) }\end{array}$ & $\begin{array}{c}\text { Mean } \\
\text { Difference }\end{array}$ & $\begin{array}{c}\text { 95\% Confidence } \\
\text { Interval of the } \\
\text { Difference }\end{array}$ \\
\cline { 3 - 4 } & & &
\end{tabular}

Lower Upper

\begin{tabular}{lllllll}
\hline Brand & 39.300 & 63 & .000 & 3.50260 & 3.3245 & 3.6807 \\
Customer & 37.610 & 63 & .000 & 3.54688 & 3.3584 & 3.7353 \\
\hline
\end{tabular}

From above table given, we conclude that the hypothesis is accepted because the significant value is less than threshold value $\mathrm{P}<0.05$; that shows that consumer satisfaction has a positive and significant effect on brand loyalty.

Table 4: Customer satisfaction mediates the relationship between pricing strategy and brand loyalty.

\begin{tabular}{lcccccc}
\hline & $\mathbf{t}$ & df & $\begin{array}{c}\text { Sig. (2- } \\
\text { tailed) }\end{array}$ & $\begin{array}{c}\text { Mean } \\
\text { Difference }\end{array}$ & \multicolumn{2}{c}{$\begin{array}{c}\text { 95\% Confidence } \\
\text { Interval of the } \\
\text { Difference }\end{array}$} \\
\cline { 3 - 7 } & & & & & Lower & Upper \\
\hline Brand & 39.300 & 63 & .000 & 3.50260 & 3.3245 & 3.6807 \\
Customer & 37.610 & 63 & .000 & 3.54688 & 3.3584 & 3.7353 \\
Price & 43.237 & 63 & .000 & 3.37891 & 3.2227 & 3.5351 \\
\hline
\end{tabular}

From above table given, we conclude that the hypothesis is accepted because the significant value is less than threshold value $\mathrm{P}<0.05$; that shows that customer satisfaction mediates the relationship between pricing strategy and brand loyalty.

Table 5: Customer satisfaction mediates the relationship between service quality and brand-loyalty.

\begin{tabular}{lcccccc}
\hline & $\mathbf{t}$ & df & $\begin{array}{c}\text { Sig. (2- } \\
\text { tailed) }\end{array}$ & $\begin{array}{c}\text { Mean } \\
\text { Difference }\end{array}$ & \multicolumn{2}{c}{$\begin{array}{c}\text { 95\% Confidence } \\
\text { Interval of the } \\
\text { Difference }\end{array}$} \\
\cline { 3 - 7 } & & & & & & \multicolumn{2}{c}{ Lower } & Upper \\
\hline Brand & 39.300 & 63 & .000 & 3.50260 & 3.3245 & 3.6807 \\
Customer & 37.610 & 63 & .000 & 3.54688 & 3.3584 & 3.7353 \\
Service & 49.794 & 63 & .000 & 3.40848 & 3.2717 & 3.5453 \\
\hline
\end{tabular}

From above table given, we conclude that the hypothesis is accepted because the significant value is less than threshold value $\mathrm{P}<0.05$; that shows that customer satisfaction mediates the relationship between service quality and brand-loyalty.

Table 6: Customer level of trust moderates the relationship between customer satisfaction and brand loyalty.

\begin{tabular}{lcccccc}
\hline & $\mathbf{t}$ & $\mathbf{d f}$ & $\begin{array}{c}\text { Sig. (2- } \\
\text { tailed) }\end{array}$ & $\begin{array}{c}\text { Mean } \\
\text { Difference }\end{array}$ & \multicolumn{2}{c}{$\begin{array}{c}\text { 95\% Confidence } \\
\text { Interval of the } \\
\text { Difference }\end{array}$} \\
\cline { 3 - 7 } & & & & & Lower & Upper \\
\hline Brand & 39.300 & 63 & .000 & 3.50260 & 3.3245 & 3.6807 \\
Customer & 37.610 & 63 & .000 & 3.54688 & 3.3584 & 3.7353 \\
Trust & 44.049 & 63 & .000 & 3.53906 & 3.3785 & 3.6996 \\
\hline
\end{tabular}

From above table given, we conclude that the hypothesis is accepted because the significant value is less than threshold value 0.05 ; that shows that customer level of trust moderates the relationship between customer satisfaction and brand loyalty

\section{Discussion}

In this research, our aim was to check the effect price and service quality on brand loyalty and to check the mediating effect of consumer satisfaction with the moderator as level of trust. For that purpose, we developed five hypotheses based on literature review and we have assumed to show a positive and significant effect of IV and DV.

After conducting the statistical analysis, our findings suggest that price has a positive and significant effect on brand loyalty and by looking at the table of ANOVA which has shown the direct effect of price on brand loyalty which also shows that our H1a is accepted but H1b has been rejected. For example, if a brand use beneficial pricing strategy in the products then it may have a positive impact on customer satisfaction which ultimately lead the customer toward loyalty. Although, our findings also have the support of 
previous researchers. For instance, Mustafa, Nafees and Aftab (2019) argue that country which we are living in, is mostly based on middle class mostly based on middle class, because of this factor every marketer is reducing his prices to retain customer. Similarly, (Natalia, 2015) suggested that to make consumers happy, firms should lower their prices to retain their loyal customers. Customers are a great asset for firm these days, because of this; firms are moving towards customization that is concentrating a great deal on customer relationship Management. In addition to the above, (Malik, 2012) argue that customers mostly get involved to those products whose prices are reasonable and matches to the customer demand.

In addition to the above, our findings also suggest that service quality also has a positive and significant effect on brand loyalty and by looking at the ANOVA which shows direct effect of service quality on brand loyalty which also make us say that our $\mathrm{H} 2 \mathrm{a}$ is accepted but $\mathrm{H} 2 \mathrm{~b}$ has been rejected. For example, if a brand offer quality products and services to the customers then the customers will be more loyal to that brand than any other brand. Although, this research finding also supported by numerous researchers. For example, Moreira and his colleague (2017) argue that are far more difficult to differentiate due to their four factors of inseparability, intangibility, perishability and variability. Similarly, Mustafa and his colleagues (2019) argue that customer purchase and repurchase of a product/service or brand could be affected by its service quality. Hence, both service quality and price are important drivers of brand loyalty.

Moreover, our findings also suggest that all our hypothesis has been accepted and have rejected the null hypothesis. But, when we have tried to show the mediating effect of consumer satisfaction on price and service quality, according to our results it shows insignificant value which has made it clear that no mediating relation exist between them.

\section{Conclusion}

To make the customer loyal is ultimate dilemma of every organization. Once an organization able to generate the customer loyalty, it could not achieve the maximum profit or could also achieve sustainable competitive advantage along with growth. Hence, this research is comprising with the postulations that by focusing pricing strategies and service quality a firm could able to generate brand loyalty. Our statistical results prove the notion that good service quality and effective pricing strategies could lead customer toward brand loyalty. Hence, we suggested that, if manager could focus these two important factors such as price and service quality, they could generate brand loyalty more rapidly and could easily compete with other players in the market.

\section{Limitation and Future research \\ Limitations}

As an old saying "practice makes a man perfect, but nobody is perfect". Hence, our research also has a couple of limitations.

First, in this research we only target the consumer of telecommunication industry. Hence, future researchers are encouraged to take the sample from other industries as well such as beverages, food and other services industries like banks etc. and compare the results of this study in the context of brand loyalty. Second, this research has been conducted in Pakistani contexts. As
Mustafa and others (2019) argue that the shopping behaviours of shopper of western countries is different from the behaviour of shoppers in Pakistan. Hence, future researchers are encouraged to replicate the findings of this research in other countries such as western context.

\section{Future research}

One future research is, other researchers are encouraged to test the moderating effect of level of trust on brand loyalty. Second, due to shortage of time future researchers are encouraged to do longitudinal study which was not possible in this limited time span.

\section{References}

Anderson, E. W. (1993). The antecedents and consequences of customer satisfaction for firms. Marketing Science, 12(2), 125-143.

Azar, S. L. (2018). Brand gender-bending: The impact of an endorsed brand strategy on consumers' evaluation of gendered mixed-target brands. European Journal of Marketing, 52(7-8), 1598-1624.

Baghestani, H. \&. (2017). Does customer satisfaction have directional predictability for US discretionary spending? Applied Economics, 49(54), 5504-5511.

Bıçakcıŏlu, N. İ. (2018). Antecedents and outcomes of brand love: the mediating role of brand loyalty. Journal of Marketing Communications, 24(8), 863-877.

Bojei, J., Julian, C. C., Wel, C. A. B. C., \& Ahmed, Z. U. (2013). The empirical link between relationship marketing tools and consumer retention in retail marketing. Journal of Consumer Behaviour, 12(3), 171-181

Bryman, A. (2004). Qualitative research on leadership: A critical but appreciative review. The Leadership Quarterly, 15(6), 729-769.

Carroll, B. A. (2006). Some antecedents and outcomes of brand love. Marketing Letters, 17(2), 79-89.

Chao-Chin, H. (2017). he impacts of brand experiences on brand loyalty: mediators of brand love and trust. Management Decision, 55(5) 915934.

Coulter, K. S. (2012). Customer engagement in a Facebook brand community. Management Research Review, 35(9), 857-877.

Delgado-Ballester, E. M.-A., \& Yague-Guillen, M. J. (2003). Development and validation of a brand trust scale. International Journal of Market Research, 45(1),35-54.

Dessart, L., Veloutsou, C., \& Morgan-Thomas, A. (2015). Consumer engagement in online brand communities: A social media perspective. Journal of Product \& Brand Management, 24(1), 28-42.

Diallo, M. F. (2015). How do price perceptions of different brand types affect shopping value and store loyalty?. Psychology \& Marketing, 32(12), 1133-1147.

Gorla, N. S. (2010). Organizational impact of system quality, information quality, and service quality. The Journal of Strategic Information Systems, 19(3), 207-228.

Grohmann, B. (2009). Gender dimensions of brand personality. Journal of Marketing Research, 46(1), 105-119.

Gustafsson, A. \&. (2004). Determining attribute importance in a service satisfaction model. Journal of Service Research, 7(2), 124-141.

Hair, J. F. (1998). Multiple linear Regression. In J. F. Hair, Multivariate data analysis (pp. Vol. 5, No. 3, pp. 207-219). Upper Saddle River, NJ: Prentice hall.

He, H. \&. (2011). CSR and Service Brand: The mediating effect of brand identification and moderating effect of service quality. Journal of Business Ethics, 100(4), 673-688.

Hollebeek, L. D. (2014). Consumer brand engagement in social media: Conceptualization, scale development and validation. Journal of Interactive Marketing, 28(2), 149-165. 
Hoxby, C. M. (2012). The missing" one-offs": The hidden supply of highachieving, low income students. National Bureau of Economic Research, No. w18586.

Jamshidi, D. K. (2018). Mobile banking behavior and flow experience: An integration of utilitarian features, hedonic features and trust. International Journal of Social Economics, 45(1), 57-81.

Kabadayi, E. T. (2012). Brand trust and brand affect: Their strategic importance on brand loyalty. Journal of Global Strategic Management, 11(6), 81-88.

Kaufmann, H. R. (2016). Exploring behavioural branding, brand love and brand co-creation. Journal of Product \& Brand Management, 25(6), $516-526$.

Kim, W. G., Lee, S., \& Lee, H. Y. (2007). Co-branding and brand loyalty. Journal of Quality Assurance in Hospitality \& Tourism, 8(2), $1-23$.

Langner, T. B. (2016). Falling in love with brands: A dynamic analysis of the trajectories of brand love. Marketing Letters, 27(1), 15-26.

Lieven, T. \&. (2016). The impact of brand gender on brand equity. International Marketing Review, 33(2), 178-195.

Lieven, T. G. (2015). The effect of brand design on brand gender perceptions and brand preference. European Journal of Marketing, 49(1/2), 146-169.

Loureiro, S. M. C., Lopes, R., \& Kaufmann, H. R. (2014). How brand personality, brand identification and service quality influence service brand equity. Cogent Business \& Management, 1(1), 981329.

Machado, J. C.-d.-C. (2019). Brand gender and consumer-based brand equity on Facebook: The mediating role of consumer-brand engagement and brand love. Journal of Business Research, 96, 376-3.

Malik, M. E. (2012). Impact of Brand Image, Service Quality and price on customer satisfaction in Pakistan Telecommunication sector. International Journal of Business and Social Science, 3(23), 123-129.

Men, L. R. (2013). Beyond liking or following: Understanding public engagement on social networking sites in China. Public Relations Review, 39(1), 13-22.

Carrizo-Moreira, A., Freitas-da Silva, P. M., \& Ferreira-Moutinho, V. M. (2017). The effects of brand experiences on quality, satisfaction and loyalty: An empirical study in the telecommunications multiple-play service market. Innovar, 27(64), 23-36.

Mustafa, M. B. (2019). Why not with the flow? A case of online shoppers in Pakistan toward online shopping. conference book, (p. 52).

Natalia, R. (2015). Understanding brand loyalty of the store brand's customer base. Journal of Product \& Brand Management, 24(7), 679692.

Netemeyer, R. G. (2004). Developing and validating measures of facets of customer-based brand equity. Journal of Business Research, 57(2), 209-224.

O'Cass, A. \&. (2011). Examining the firm's value creation process: A managerial perspective of the firm's value offering strategy and performance. British Journal of Management, 22(4), 646-671.

Oliver, R. (1999). Whence Consumer Loyalty? Journal of Marketing, 63(4_suppl1), 33-44.

Pitt, L. F. (1995). Service quality: A measure of information systems effectiveness. MIS Quarterly, 19(2), 173-187.

Punniyamoorthy, M. \&. (2007). An empirical model for brand loyalty measurement. Journal of Targeting, Measurement and Analysis for Marketing, 15(4), 222-233.

Schlesinger, W. C.-C. (2017). Sticking with your university: the importance of satisfaction, trust, image, and shared values. Studies in Higher Education, 42(12), 2178-2194.

Simon, F. \&. (2018). Does brand-consumer social sharing matter? A relational framework of customer engagement to brand-hosted social media. Journal of Business Research, 85, 175-184.
Swartz, T. \&. ((2000)). Handbook of services marketing and management. Sage.

Van Doorn, J. L. (2010). Customer engagement behavior: Theoretical foundations and research direction. Journal of Service Research, 13(3), 253-266.

Vernuccio, M. P. (2015). Antecedents of brand love in online networkbased communities. A social identity perspective. Journal of Product \& Brand Management, 24(7), 706-719.

Yoo, B. \&. (2001). Developing and validating a multidimensional consumer-based brand equity scale. Journal of Business Research, 52(1), 1-14.

Table of Reference

\begin{tabular}{|l|l|l|l|}
\hline Concept & Dimensions & $\begin{array}{l}\text { Question } \\
\text { number }\end{array}$ & References \\
\hline $\begin{array}{l}\text { Brand } \\
\text { Coyalty } \\
\text { satisfaction }\end{array}$ & Trust & Q1-Q2 & $\begin{array}{l}\text { Adapted } \\
\text { (Delgado-Ballester \& Yague- } \\
\text { Guillen, 2003) }\end{array}$ \\
\hline & Trust & Q3-Q5 & $\begin{array}{l}\text { Adapted } \\
\text { (Kabadayi, 2012) }\end{array}$ \\
\hline Price & Assurance & Q9-Q12 & $\begin{array}{l}\text { Adopted } \\
\text { (Punniyamoorthy, 2007) }\end{array}$ \\
& Preference & Q6-Q8 & $\begin{array}{l}\text { Adopted (Punniyamoorthy, } \\
\text { Adopted (Netemeyer, 2004) }\end{array}$ \\
\hline $\begin{array}{l}\text { Level of } \\
\text { trust } \\
\text { quality }\end{array}$ & Trust & Q25-Q28 & Adopted \\
(Delgado-Ballester \& Yague- \\
Guillen, 2003)
\end{tabular}

